\title{
LIFE-GIVER: THE PRE-HISPANIC NAHUA CONCEPT OF "FATHER" THROUGH COLONIAL WRITTEN SOURCES
}

\author{
Julia Madajczak \\ Faculty of Artes Liberales, University of Warsaw, Dobra 72, 00-312 Warsaw, Poland
}

\begin{abstract}
This paper explores the ancient Nahua concept of "father," employing early Colonial sources written in both Nahuatl and Spanish. A careful contextual analysis of the occurrences of various Nahuatl terms for "father" or "parent" leads to the conclusion that the principal criterion for creating their metaphorical extensions differed considerably from parallel Spanish criterion. While the latter referred to the power relationship ("father" is the one who governs), the former was based on the concept of exchange ("father" is the one who gives). This principle has implications for studying many aspects of Nahua culture in which the terms for "father" appear: gender and social roles, political hierarchy, pre-Hispanic religion, or evangelization. The difference in the construction of such basic concepts in Nahuatl and Spanish leads to methodological considerations about studying sources that have arisen from the context of cultural contact.
\end{abstract}

\section{INTRODUCTION}

The encounter of European and Mesoamerican cultures has long fascinated scholars, who, for the past several hundred years, have shifted perspectives and approaches in an attempt to incorporate this subject into the discourse of Western academia. Focusing at first on civilizational benefits for Native Americans, then mourning the destruction of their indigenous cultures, we have now reached the point in which we try to understand the ways indigenous peoples faced cultural challenges brought on by colonization. Such a focus requires, more than ever, a thorough reconstruction of precontact worldviews and, in the case of the Nahuas, the largest linguistic group of the Aztec state, the task has a chance of success, thanks to the existence of extensive historical sources related to this group. Although the entire corpus includes a diversified set of architectural, iconographic, and written (both in the native writing system and in Roman alphabet) sources, this paper will only use textual evidence. The reason for such limitation is that the topic deals specifically with linguistic data: old terminologies that could have only been preserved in texts written in Nahuatl or Spanish. The production of texts, especially in the early stages of colonization, was most often inspired or directly executed by the Spanish friars, and the sources that are of interest heredescribing precontact customs and beliefs - arose from the desire to Christianize the Nahuas. Under such circumstances, even the earliest, sixteenth-century documents, can hardly be expected to record with exactitude pre-Hispanic terminologies and manners of speaking. Rather, they include bits of an older Nahua terminological system intertwined with the system of the Spaniards and the hybridization of both that, along with linguistic innovations, emerged from bilingual centers of cultural and textual production. Reading Nahuatl

E-mail correspondence to: julia@al.uw.edu.pl sources is, therefore, often confusing, especially when it comes to interpreting metaphors, such as the one chosen to discuss here, "father." Did the Nahuas understand this basic category in the same way as Spaniards understood it or as we now understand it? How are we to distinguish Nahua and Spanish usages of this term in the texts?

In Nahuatl, the term that is the closest equivalent of the Spanish "padre" is -tah. Throughout this article I indicate glottal stops in Nahuatl words with $h$, but do not mark vowel length. Words borrowed from Spanish are written according to the modern standard for Spanish. All short expressions or terms in Nahuatl used in the text are standardized; longer passages quoted with their translations are given in the original orthography of the source. For writing Nahuatl kinship terms I use a convention established by Lockhart (1992) — a noun stem with a hyphen — which reveals the first major difference between the two concepts. -Tah, as all Nahuatl kinship terms, necessarily needs to be possessed, either by a defined person (notah, "my father," totah, "our father") or by an undefined "someone" referred to with an indefinite possessive pronoun (tetah, "one's father" or "the father of people"). Along with kin terms, Nahuatl has other necessarily possessed terms, among them terms for body parts and some concepts related to personhood, such as -ixiptla or -tonal when it refers to animistic force.

Spanish friars Christianized the Nahuas employing their own language-Nahuatl-and the concept of "father" had to be one of the first to deal with. The Holy Trinity includes God the Father (Dios Padre), God the Son and God the Holy Spirit. The head of the Catholic Church is known as "Holy Father" (Santo Padre), while friars and secular priests are commonly referred to as "fathers" (padres). This title is likewise ascribed to male saints or to early Church Fathers, and humankind is believed to come from "the father of all," Adam. Even more importantly, upon the 
arrival of Christianity the concept of "father" was already present in precontact Nahua religion. Both fire and the god of fire (Xiuhteuctli or Huehuehteotl) were called "our father" (totah) (Sahagún 2012: bk. 1 , p. 72 , bk. 2 , p. 159). The same name was ascribed to the cosmic tree, standing at the center of the world (Durán 2005: 140-141). During the feast Xocotl Huetzi, a person charged with bringing the impersonator of Huitzilopochtli down from the pyramid was called "his father or elder brother" (itah anozo iach) (Sahagún 2012:bk. 2, p. 115). Finally, in the songs various deities referred to their priests as "my fathers" (notahhuan) (Sahagún 1997:133-137).

The precontact and Spanish metaphorical connotations of "father" coexist in sources and it is impossible to study the former separately from the latter. Numerous scholars have already called the attention of their readers to the dialectic nature of Colonial sources. Burkhart (1989:6-22) points to the fact that many written pieces were the result of close collaboration between the Spanish editor and his native "informants," who, however, wrote large portions of the text—often quite independently from their supervisor. On the other hand, the indigenous writers took advantage of Spanish oral testimonies and written sources, as well as of European genres and literary conventions. They were educated in a European manner, in schools directed by ecclesiastics and, at least officially, their religion was Christianity. At the same time, the Colonial Nahuas entered into the dialogue with their own tradition, re-creating their vocabularies and ways of expression, as well as their accounts of the past. In terms of language, they engaged both precontact resources of Nahuatl and innovations brought by the Spanish language and culture (including the friars' deliberate translations of Christian terms) in a creative process of response to historical circumstances. Anderson et al. (1976), Burkhart (1989, 2001), Cline and León-Portilla (1984), Karttunen and Lockhart (1976), Lockhart (1992), Schwaller (2006), Sigal (2011) and Tavárez (2000), to name only a handful of publications, demonstrate how Spanish terms were adapted by Nahuatl, which, concurrently, modified its original vocabulary to describe the Colonial reality.

The transfer of the Nahuatl -tah to the discourse of Christian religion could not have been entirely transparent. The words padre and -tah were distinct in terms of both their use within the language and their religious connotations. Moreover, each of them was based on a different cultural construction of the concept of "father," itself rooted in a different background of relations between genders. Throughout Mesoamerica, male-female complementarity was, before the Spanish conquest, an important aspect of social and ideological systems, though in practice the level of egalitarianism differed among societies (Joyce 2000:97-120; Kellogg 2005a: 18-34). Gender roles in Nahua culture have been studied on the basis of various types of written sources: lawsuits (Kellogg 2005b), censuses (McCaa 2000), historical accounts (Klein 2001) or speeches of the elders (Joyce 2000). While early scholars stressed the dominant position of Nahua men, more recent publications pointed to complementary roles of men and women, eventually painting a complex image of tensions between gender parallelism and gender hierarchy in early sixteenth-century Nahua culture (Kellogg 2005a:19-29; McCafferty and McCafferty 1988). The former was mostly visible in ideological sphere, reflected in masculine-feminine identities of important deities, in household rituals replete with symbols of war, or in cognatic kinship system (Burkhart 1997:26; Joyce 2000:169-175; Kellogg 1986). At the same time, women had limited access to power and often married at a very young age in comparison to men. Femininity was also lowly valued in Nahua discourse that associated men with strength and victory, whereas "women's talk" was considered tricky and deceitful (Kellogg 2005a:24; McCaa 2000). While not ideally egalitarian, Nahua gender relations were, nevertheless, quite shocking in the eyes of sixteenth-century patriarchal Spaniards. Indigenous women's activity in early colonial courts and the public sphere in general was critically commented upon by contemporary Spanish observers (Kellogg 1997).

Nahua kin categories, as well as the Nahua concept of kinship, remain largely unexplored. The scholars who have dealt with the topic of kinship focused mainly on the reconstruction of the model of a broadly conceived "family" on the basis of kin terms, even though they pointed to a rich employment of this terminology for metaphorical purposes (Carrasco 1966; Díaz Rubio 1986; Gardner 1982; Karttunen and Lockhart 1987; Lockhart 1992; Offner 1983; Pizzigoni 2012; Rammow 1964). Some of the collective terms, such as tlacamecayotl, teixhuihuan or huanyolqueh have received the attention of scholars and have been extensively discussed (Calnek 1974; Kellogg 1986; Lockhart 1992; Offner 1983). López Austin (1984) approached the topic of the ideology of kinship in his study on the human body among the Nahuas. Regarding kin categories, even basic ones, such as "father," "mother" or "child," none of the scholars cited above have gone beyond Book 10 of the Florentine Codex, which describes ideal models for a broad range of relatives (Sahagún 2012:bk. 10, pp. 1-9).

The present paper aims to fill this gap at least partially by examining metaphorical usages of various terms for "father" in Nahuatl sources. I use the term "metaphor" with the sense of "a displacement and an extension of the meaning of words," as defined by Ricoeur (2003:1). Douglas (1999:252-267) suggests viewing such linguistic metaphors as the points of overlapping classificatory systems and considers them important tools for studying criteria of cultural classification. Her approach will help in retrieving elements of the precontact construction of "father" from the mass of Colonial evidence. In order to do so, I will first discuss Nahuatl metaphors that resulted from the European-Christian worldview and were, most often, calques of Spanish metaphors. This will be followed by an analysis of preserved contexts for the precontact metaphorical use of "father" and by an attempt to understand logical principles that lay behind this particular cultural concept. Since it is not always possible to draw a firm line between Spanish-originating and pre-contact Nahua metaphors, I will also point to usages that arose from merging of the two sets of concepts. Finally, Spanish and Nahua systems will be compared in order to provide clues for further interpretation of metaphors in Nahuatl texts, as well as to draw conclusions regarding the pre-Hispanic worldview.

\section{SPANISH METAPHORS IN NAHUATL SOURCES}

"Father" is one of the most basic kinship concepts. For a modern Westerner, an ideal "nuclear" family consists of a father, a mother, and one or more children. As occurs with every concept that lies at the foundation of the entire society, "father" is apt to be treated as a universal idea. It means that although sixteenthcentury Spaniards, precontact Nahuas or twenty-first-century Westerners have their own models of "father," they would all tend to extrapolate them, without much reflection, to other peoples and cultures. Basic kinship concepts are usually treated as "natural" and, yet, they are complex cultural constructions that involve many aspects (biological, social, and ritual) and change over time. 
Metaphorical usages of the term padre (literally defined in relation to a child, i.e., the father is the one who has, or engenders, a child) in the early seventeenth-century dictionary of Covarrubias and the eighteenth-century dictionary of the Academia de Autoridades provide clues as to the understanding of this concept in Colonial Spain. In the older source "father" is a title of respect employed in regard to ecclesiastics and elderly men (Covarrubias Orozco 1611). The more recent dictionary adds other meanings: the leader of a family or a nation (pueblo), the author of a piece of art or any other work. The term is also firmly associated with procreation - a bull selected to be the procreator in a herd is called padre (Real Academia Española 1726-1739). Thus, in the Castilian language of the late Colonial period, three aspects of paternity were particularly stressed: procreative functions, authority, and the role of being the origin of things. Accordingly, they stand behind the Christian usages of padre already mentioned. For instance, God the Father is believed to be the origin of the universe, to have power over the people, and to have engendered his Son Jesus Christ. The Spanish term padre that entered written Nahuatl in the midsixteenth century (it is known from the Doctrina cristiana en lengua española y mexicana por los religiosos de la orden de Santo Domingo [Anonymous 1548:f. XV]) was charged with these connotations. It did not function as a kin term but, rather, as a metaphor for God, ecclesiastics, and the pope, Santo Padre.

It is important to remember that the encounter of cultures that produced alphabetic sources in Nahuatl was not a mere clash of ways of expression (writing), conventions (genres), and terminologies. It was a contact of deep cultural structures, completely different worldviews, and ways of thinking based on distinct logical criteria. One of the main purposes of adapting the Spanish alphabet to Nahuatl was evangelization and, for this reason, the topic of religion and religious background (e.g., in testaments) stands out in Nahua literature. Spanish metaphors built around the concept of "father" with the use of the term -tah abound in these texts, muffling the original pre-Hispanic Nahua conceptions, and creating a false impression that the two metaphorical systems were, in fact, identical. Colonial testamentary formulae involved statements such as: "[f]irst of all, as for my soul, I place it entirely in the hands of my beloved and revered father, God" (Ca huel acachtopa yn noyolia Nanimantzin $\mathrm{Ca}$ huel ycenmactzinco nicontlalia in notlaçomahuiztahtzin Dios; Pizzigoni 2007:55) and the first person of the Trinity, "God the Father," was commonly rendered as dios tetahtzin. It seems that two Nahuatl possessive prefixes: te-, "one's, people's" and to-, "our," could turn necessarily possessed kin terms into generic terms, so that when convenient, it was possible to omit them in translation into Spanish. Thus, tetahtzin, "a father of someone (reverential)," and totahtzin, "our father (reverential)," were perfect choices to calque such Spanish usages of padre as "God" or "priest." In fact, totahtzin, with the meaning of "religious," was very common in Colonial sources and it undoubtedly entered the spoken language as well, because it is still used in this way in the modern variant of Huastecan Nahuatl (Wood 2016). Totahtzin was also sometimes used for saints (e.g., in Molina's (1984:73v) Confessionario mayor), but the preferred form was totlazohtahtzin, "our beloved father," or even totlazohmahuiztahtzin, "our beloved and revered father" (see Madajczak 2011). These terms, also extended to the particularly revered priests, might have been calques from the Spanish nuestro amado padre, used with the names of male saints. The root -tlazoh is known to calque amado in other expressions, for instance itlazohtzin Dios, "the beloved of God," (in Spanish, el amado de Dios) employed by the native annalist Chimalpahin $(2006: 68,86)$ for some saints and ecclesiastics.

The roots tlazoh and mahuiz, omnipresent in the Colonial Nahua Christian discourse merit their own discussion, and here it is only possible to scratch the surface of the rich complexity of their implications. The suggestion of Lockhart (1992:552, n. 208) that, after the Spanish Conquest, the element tlazoh was added to concepts from the religious sphere in order to locate them specifically in the Christian context seems too simplistic. In the late Colonial period both tlazoh and mahuiz, were indeed reduced to mere honorifics, but they likely connoted deeper meanings before contact. Bassett (2015:123-127) notes that these terms were associated with teotl, one of the major religious concepts of precontact Nahuas, most often translated as "god" or "divine force." For instance, greenstone, named xihuitl in Nahuatl, is described as "not very green, but a little dead, as if it were not very mahuizzoh, but was truly a little dirty" (amo cenca qujltic, çan achi mjcquj: iuhqujn amo çenca mavizço, çan nel achi ixtlileoac; Sahagún 2012:bk. 11, p. 223), while the name teoxihuitl means "the property, the -tonal [= attribute] of teotl and it means 'very mahuizzoh' because it does not appear much in any place, it rarely appears somewhere. This teoxihuitl is very mahuizzoh. When something is visible on it, it is not very mahuizzoh" (iiaxca, itonal in teutl, iuan, q.n. cenca mavizio; ipampa acan cenca neçi, canin zan quēman in neçi: injn teuxiujtl cenca mavizio, in itla, in jtech motta amo cenca mavizio; Sahagún 2012:bk. 11, p. 223). Mahuiz, therefore, is not only characteristic of teotl, but of something that is simultaneously rare, light, clear, and alive. Olko (2014:321) points to the fact that the abstract noun mahuizotl used to form a doublet with tleyotl (see below) in order to describe divine essences sent to the ruler by the creator deity. The association of tlazoh with the esoteric sphere is less obvious but it is possible that the implications of this term were similar to those of mahuiz. The two terms are often juxtaposed in order to describe concepts of the greatest-and often sacred-value for the Nahuas, such as speech, dynastic rulers, or children (e.g., Sahagún 2012:bk. 6, pp. 53, 83, 99). Tlazoh, similarly to mahuiz, had a connotation of esteem (Wood 2016, see the entry for tlazotla), associated with rarity and teotl. Teotetl, or "jet," "is just tlazoh, it just lives as tlazoh [= it is rare], as if it were an exclusive attribute of teotl" (çan tlaçoca çan tlaçonemj: iuhqujnma ineixcahujlteutl; Sahagún 2012:bk. 11, p. 228). In Colonial dictionaries, the roots tlazoh, mahuiz, tleyo, or teo are commonly translated as "honor," "fame," "love," "esteem," or "marvel." It is even possible that these meanings were promoted by the Spanish friars to the disadvantage of more "devilish" connotations, as is suggested by a passage from the Florentine Codex where native informants deny any "divine" implications of the word teoatl, "ocean" (Sahagún 2012:bk. 11, p. 247). At the time of contact, however, these implications may have been better understood by Nahuatl speakers. Perhaps the associations of tlazoh and tlazohmahuiz, with holiness in the early Colonial period are reminiscent of their precontact implicit meanings.

\section{PRECONTACT "FATHERS": THE SOURCES OF HEAT}

Compared to a great number of the occurrences of -tah within the Spanish metaphorical frame and in reference to Christian concepts, parallel data on the precontact "fathers" are very scarce and scattered. There are no monolingual dictionaries of Nahuatl from the Colonial period that would allow the kind of quick analysis done for the Spanish padre in the preceding section. Instead, all the 
lexical evidence we have from the vocabularies has been filtered through Spanish conceptions by means of adjusting them to Spanish glosses. The only way in which we can attempt to reach toward the Nahua idea of "father" is by reading the few texts in which -tah is employed in the context of precontact phenomena. This kind of evidence is likely to include pre-Hispanic usages of the term preserved strongly enough in the language to appear automatically, regardless of other usages already distorted by contact with Europeans.

As I have mentioned above, the title "our father" (totah) was ascribed by the Nahuas to both fire and the god of fire. This information comes from the Florentine Codex and was provided by elders questioned about titles and names of gods and about ceremonies performed during calendar feasts (López Austin 1974:123-126). When listing the names of Xiuhteuctli, they said: "Xiuhteuctli, Ixcozauhqui [= Yellow-Faced $]$ and Cuezaltzin [= Flame $]$. He was named Fire or Huehuehteotl [= Old Deity] and Our Father" (Xiuhtecuhtli: Ixcoçauhquj, yoan Cueçaltzin. Iehoatl motocaiotia in Tletl, anoço Veueteutl yoan Tota; Sahagún 2012:bk. 1, p. 72). In the description of the month Izcalli, they cited a saying: "[a]s for the tenth day of Izcalli, tamales with amaranth leaves were eaten. It is called, it was said: 'Our father, he who is fire, provides himself with something roasted" (in izcalli tlamatlacti in qualoia oauhqujltamalli, moteneoa, mitoaia, motlaxqujan tota, iehoatl in tletl; Sahagún 2012:bk. 2, p.159). Fire was not the only being called totah, however. Durán (2005:140-141) writes that, during the feast of Huey Tozoztli, dedicated to Tlaloc, the god of rain, an artificial forest was set up in the temple patio and in the middle of it stood the tallest tree that could have been found in the woods. Its name was totah and it was surrounded by four smaller trees connected to it by means of twisted ropes (Figure 1).

Heyden (1993:215), who collected numerous examples of using trees or wood in Mesoamerican rituals, suggests that the arrangement described by Durán may have represented the four limits and the center of the world. It coincides with a reconstruction of

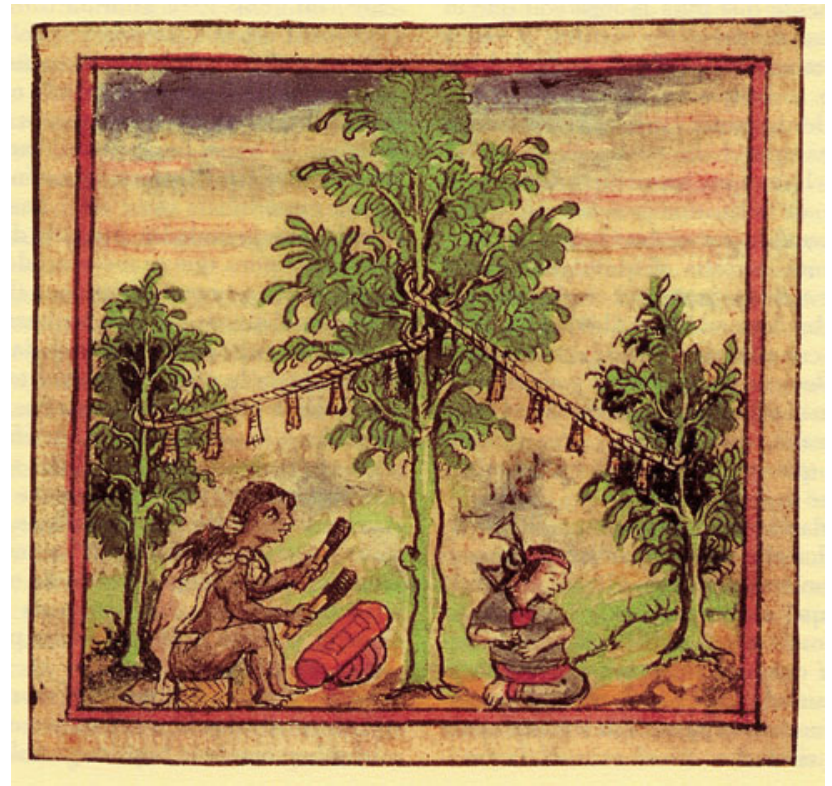

Figure 1. Totah and two of four smaller trees (Durán 1991:f. 263v). the way the Nahuas perceived the universe, made by López Austin (2000:19-21, 225) on the basis of central Mexican and Mayan sources. Space is delimited by four posts, sometimes pictured as trees, whose trunks are tunnels through which the divine essence of both masculine and feminine nature circulates, producing time and, therefore, life on earth. On Plate 15 of the Codex Borbonicus (Figure 2) the cosmic tree is composed of four different colors, forming a helix, or malinalli, interpreted by López Austin (2006:88-89) as a representation of four trees comprised in one. The trunk of the broken tree resembles a twisted rope, like one of those that in the description of Durán connect smaller posts to totah. The friar claims that these ropes were called nezahualmecatl, "the ropes of fast," and were supposed to indicate "penance and the roughness of life." He compares nezahualmecatl to a cilice, used by devoted Christians of the era to "punish their bodies" (Durán 2005: 141). Since Durán tended to confuse the Nahua practice of autosacrifice, which was not a punishment, but rather a way of communicating with gods, with the Christian-like penance, it is likely that the ropes were in fact a symbol of the former. The Codex Borbonicus displays another sign of autosacrifice-maguey spines used to draw blood from various parts of the body-stuck on top of the tree. As one of the main purposes of drawing blood was the transmission of vital essences to deities, the possible symbolic content of the twisted ropes includes the flow of essences, which, in any case, was also conceptualized as malinalli (Maffie 2015:315-317).

There is more iconographic evidence of associating the cosmic tree with the receptacle of divine essence. The reliefs on the hill of Tepetzinco include a depiction of a warrior who grasps a tree, mimicking the typical gesture of warriors grasping the hair of their captives in a sign of victory. The belief behind this iconographic convention was that the hair on the head contained a significant amount of tonalli, hot vital essence sent to humans from the heavens and particularly from the sun. Cutting hair exposed a person to the risk of losing his tonalli, which could have even resulted in his death (López Austin 1984:241-243). A warrior held by the hair was, therefore, entirely overpowered by his captor. Umberger (1999:83) proposes several interpretations of

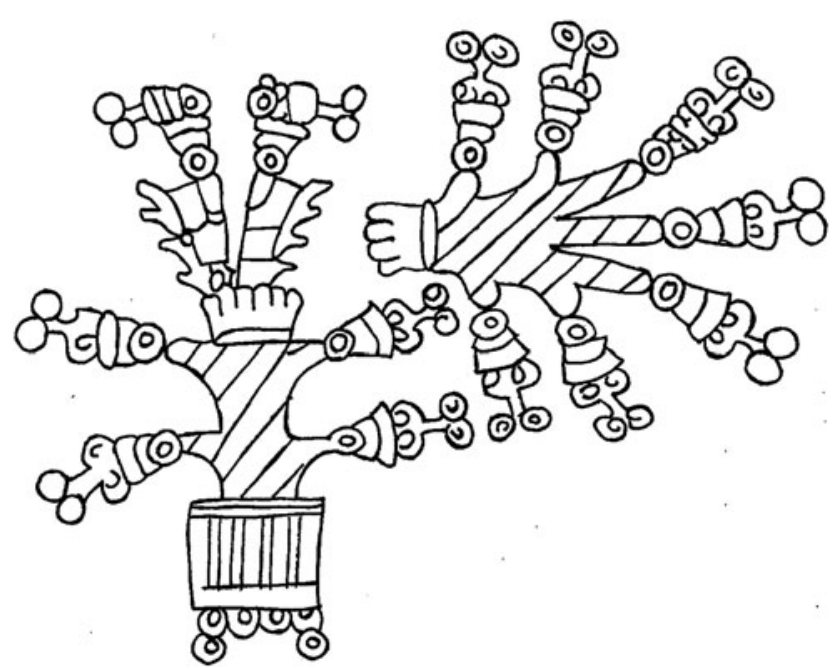

Figure 2. The broken tree of the Codex Borbonicus, Plate 15. Drawing by author (after image at http://www.famsi.org/research/graz/borbonicus/ img_pagel3.html). 
substituting the captive with the cosmic tree on the Tepetzinco relief and all of them revolve around the idea of subjugation. Most interestingly, she notes that trees were believed to be the hair of the earth and that, upon conquering a place, the uprooting of trees and other plants was performed by Aztec warriors. This suggests that tree was symbolically equivalent to hair, in that both were conceived of as keys to access the tonalli of a person or an altepetl (a Nahua state and at the same time the basis for self-identification). In each of the three examples discussed here the cosmic tree has features of a source of vital force, or, simply speaking, life.

Durán (2005:140-141) gives two explanations for naming the central tree of the Huey Tozoztli arragement "our father":

It should be noted that the figure before us was christened with the name, "father" - this is what tota means - and because of this we know that they worshipped the father, the son and the holy spirit. They said tota, topiltzin and yolometle, words meaning "our father," "our son" and "the heart of both," and worshipped them both separately and as one, wherefore the news about the Trinity that existed among these people can be noted. (...) To this tree they gave the name tota, which means "our father," because they put four smaller [trees] around it, and in this way it was like the father of the others. (Es de notar que la figura presente se soleniçaba en nonbre de padre que quiere decir tota, para que sepamos que reuerenciauan al padre y al hijo y al espiritu santo y deçian tota, topiltzin y yolometle los quales bocablos quieren decir nuestro padre y nuestro hijo y el coraçon de anbos haciendo fiesta a cada vno en particular y a todos tres en vno donde se nota lo noticia que huиo de la trinidad entre esta gente. (...) A este arbol ponian por nonbre tota que quiere decir nuestro padre a caussa de que a la redonda del ponian otros quatro mas pequeños quedando el como por padre de los demas.

We can perceive attempts to adjust the concept of "our father" to the Spanish worldview in both arguments. In spite of an obvious association of the tree with the number four, Durán looks for a trinity, because, for a Christian, if there is a father, there should also be the Son and the Holy Spirit. Although Graulich (1982:246) insisted that Totah ("Our Father"), Topiltzin ("Our Child") and Yollometl ("The Heart of Maguey") represented the solar, Venusian, and lunar aspects of the god Xipe Totec, Johansson (2002:391) noted that the otherwise unattested Yollometl seems strangely similar to the Holy Spirit. Indeed, the juxtaposition of all three names is likely to be modeled on the Christian trinity and, in the opinion of Todorov (1999:208), forms part of Durán's larger project to represent precontact rites and beliefs as imitations of Catholic religion. In the following passages, Durán himself gives another explanation of the name totah, suggesting that Our Father presided over four smaller trees. This interpretation arises from associating "father" with the "head of the family," the most important person in a group. The name of the central tree (as well as that of fire), however, is "our father," rather than "their father (of the trees)," wherefore it implies the relationship with "us." This "us" was probably understood as a community of worshippers - an altepetl or an even larger group of people.

López Austin (1984:230-233) identifies both the cosmic tree and fire as sources of tonalli, which was closely associated, or even synonymous with, tleyotl, a concept translated by Molina (1977:vol. 2, f. 147r) as "honor, fame and luminosity." Both terms imply the notion of something hot and fiery: the word tonalli derives from the verb tona, "to be warm, for the sun to shine" (Karttunen 1992: 245-246), whereas tleyotl includes the root tle, "fire" (Olko 2014:
321). Sahagún's informants stated that after a child was born, he or she was placed next to the fire and had to stay there for four days. During that time no one could take fire from the hearth so that the baby's inner "fire" will not be taken away (Sahagún 2012:bk. 4, p. 111). This custom stemmed from a belief that the child was born very cold, a result of being in his or her mother's womb, which belonged to the sexual, feminine, cold, and humid sphere of the universe (López Austin 2000:164, 172). To restore the balance, the child had to receive something fiery, something that would let him or her live. Similarly, in the constant process of circulation of essences in the trunks of the four posts or, from another point of view, in the process of the exchange of essences between the cosmic spheres (the earth and the world beyond), a man received his vital force from the cosmic tree.

The same principle of receiving something immaterial from the "father" seems to form part of a multi-faceted relationship between captives and their captors. The collaborators of Sahagún explain: "[h]e who had a captive did not really eat the flesh of his captive. He said: will I eat myself as well? For when he seizes him, he says: he is like my child. And the captive says: he is my father" (Auh in male, amo uel qujquaia, yn jnacaio imal, qujtoaia, cujx çan no ne njnoquaz: ca yn iquac caci, qujtoa, ca iuhquj nopiltzin: Auh in malli, qujtoa ca notatzin; Sahagún 2012:bk. 2, p. 54). According to the interpretation of Olivier (2004:397-398, 2010: 466), the captor offered his captive to the gods as a substitute victim. This means that the victim acquired the identity of a captor who, in this way, actually sacrificed himself and thus benefited from communication with deities.

Frequently, priests are named "fathers" of gods to whom they serve. In the description of the feast of Xocotl Huetzi, recorded by Sahagún, it is said that the statue of the manifestation of Huitzilopochtli named Painal was carried to the top of the pyramid and then brought down by a priest called "his father or his elder brother" (Sahagún 2012:bk. 2, p. 115). In the Crónica Mexicayotl, migrating deities are borne by priests called teomamaqueh, "god-carriers," who are also labeled as their "fathers." The term is employed as an address, when Huitzilopochtli and Malinalxochitl speak to their priests: "Huitzilopochtli said to those who were god-carriers: 'my fathers, you are still to wait for what will happen" (auh in yehuantin in yn teomamaque oquimilhui yn huitzilopochtli. notahuane. yn tleyn mochihuaz oc xicchiyecan; Chimalpahin and Tezozomoc 1997:84) or "when Malinalxoch woke up, she wept, she said to her fathers: 'My fathers, where will we go?'” (yn ohualliçac niman ye choca yn mallinalxoch. quimilhuia yn ittahuan nottahuan campan tiazque; Chimalpahin and Tezozomoc 1997:78). Similar to captors who shared their identity with captives for the purpose of sacrifice, priests were identified with their patron deities. They shared costumes, names, body painting, and attributes. In sixteenth-century sources—such as the Crónica Mexicayotl-they are sometimes confused with each other (Contel and Mikulska 2011:33-39). At the same time, the nomenclature employed in regard to the priests suggests that they were considered the "givers" in the process of communication with the deities. The generic term (see the discussion in Contel and Mikulska 2011: 31-32) for "priest," tlamacazqui, includes the root maca, "to give"; tlamaca specifically means "to feed" (Karttunen 1992:278), and after the Spanish conquest it was employed for dispensing communion (Lockhart 2001:223). On the other hand, the high-ranking priests bore the title tlenamacac, which can be rendered as "fire seller." The "economic" concepts of "giving" and "selling," as well as that of "paying what is due" (nextlahualiztli [Köhler 2001:126]), a term employed for 
sacrifice, evoke the Nahua belief in the continuous exchange of goods and services between deities and humans. In the case of the latter, the main actor was a priest-the "father" of deities. Thus, the concept of "father" is again associated with the transmission of something, which, at least in the case of tlenamacac, is hot and fiery.

\section{THE BIOLOGICAL AND SOCIAL ROLES OF NAHUA FATHERS}

The examples cited above prove that the logical principle that governs the metaphorical extensions of the term -tah in the Nahuatl terminological system is very different from what we find in Colonial Castilian. It does not refer to a hierarchical order, where the father is placed either at the beginning or on top of things. This is consistent with gender complementarity characteristic of Mesoamerican cultures. Although the warlike Nahuas praised male strength and other traits ascribed to valiant warriors, their understanding of masculinity cannot be reduced to dominance over negatively valued femininity. Complementary roles of men and women in the ideological sphere are exemplified by a belief that deceased warriors accompanied the sun from its rise until noon, when it was taken over by women who died in childbirth. This daily journey was thus composed of two legs, each of them associated with either hot and fiery masculinity (noon as the milestone) or cold and humid femininity (the underworld, where the sun entered to travel through the night, as the milestone). In Nahuatl, the west was called cihuatlampa, or "toward the women," suggesting their strong connection with the dark place where the sun set (Burkhart 1997:32). On the other hand, the link between "fatherhood" and "fire" correlates with heat as an important aspect of the Nahua construction of masculinity.

The analysis presented above reveals that an important element of the native concept of "father" was transmission of vital essences. At the biological level, this transmission could have been understood in terms of conception. Modern data quoted by López Austin (1984:336-337) indicate that, among the twentieth-century Nahuas of central Mexico, the body of a fetus was believed to be formed of the paternal semen that accumulated in the mother's womb. This belief is shared by other Mesoamerican communities, such as the Mixtecs of Santiago Nuyoo (Monaghan 1995:195). Book 6 of the Florentine Codex is not so direct, but it implies that precontact Nahuas understood that sperm played an important role in the formation of a child (Szoblik 2007):

And the midwife commands the pregnant woman that before the baby is complete, which is after one, two, three months, she and her husband should have sex sometimes so that the baby becomes complete. Otherwise it will just be sick, it will shake when it goes out into the world. (Ioan qujnaoatia in ticitl in otztli: in aiamo onmaci piltzintli, in qujn ce, in qujn vme, in qujn ei metztli, ça oc quenman moquazque in jnamjc, injc onmaciz piltzintli, intlacamo, ca çan cocoxquj, amo tevivi in tlalticpac qujçaz; Sahagún 2012:bk. 6, p. 156).

The information that the insufficient amount of sperm "given" to the fetus led to the child's sickness suggests special qualities of semen. In the worldview of the colonial Nahuas the most frequent cause of disease was the loss of tonalli (López Austin 1984: 247-251; Ruíz de Alarcón 1987:161) and there are reasons to believe that sperm was a carrier of this hot essence. In Book 6 of the Florentine Codex, a father warns his son about dangerous and deadly effects of having too much sex. He implies that frequent ejaculations are like squeezing juice out of a fruit (tepatzcac): a man wrinkles up, withers away and finally dies (Sahagún 2012:bk. 6, pp. 125-126). The verb ihtlacoa, "to damage something," which gave origin to the Christian-Nahuatl term tlahtlacolli, "sin," also meant "to get sick because of frequently giving oneself away to women" (Molina 1977:vol. 2, f. 43r). This evidence suggests a belief that ejaculation deprived a man of his vital force. Logically, women did not seem to lose anything during intercourse- to the contrary-wherefore, as it is implied in an often-cited passage from the Florentine Codex, they could have enjoyed sex until an advanced age (Sahagún 2012:bk. 6, pp. 118-119). Perhaps what both women and fetuses received from men was tonalli, as modern ethnographic data point specifically to this essence as the one that leaves the body during sex (López Austin 1984:243).

A term given by Molina (1977:vol. 2, f. 48v) for "biological father" (padre natural) is izcacauhtli. It is an agentive noun derived from the unattested verb izca ("the one who does izca"). The concept on which the term for the biological father was based can, however, be inferred from other known derivatives. The patientive noun izcalli ("a result of doing izca")—at the same time a name of a month and a feast day-apparently meant "growth." Referring to the feast day, the collaborators of Sahagún explained: "[t]he reason why it is called Izcalli is that then they seized all the children by the neck. It was said that with this they seized them by their buds, their outgrowths, so that they quickly become trees [i.e., tall? mature?]" (Auh injc moteneoa Jzcalli: vncã qujnquechanaia in jxqujchtin pipiltotonti: qujlmach, ic qujmjzcalloana: qujmjzcalana, injc iciuhca quauhtiazque; Sahagún 2012:bk. 2, p. 165). The agentive izcalloh ("something covered with izcalli") was used to describe a bud (Molina 1977:vol. 2, f. 49r). The causative izcaltia ("he causes someone to have the quality of an izcalli") was glossed by Molina (1977:vol. 2, f. 49r) as "to raise a child." Another causative, izcalia ("he causes himself to izca"), meant "to revive, to regain consciousness, or to resuscitate" when reflexive, while the non-reflexive form ("he causes another person to izca") has been rendered as "to bring someone to life or to teach him and correct him by means of speech or punishment." While izcalli and izcaltia connect izca with growing or maturing, izcalia brings out the concepts of living and-surprisingly-of educating. Possibly, all three of them should be taken into account when interpreting the category of izcacauhtli as the one who both physically makes his children live and grow (as described above) and educates them. The social aspect of fatherhood was certainly important for the collaborators of Sahagún, who stated that a model Nahua father "rears children, he is their tutor, he raises people, he educates them, he advises them, he admonishes them" (tlacazcaltia, tlacauapaua, teizcaltia, teizcalia, tenonotza, tenotza; Sahagún 2012:bk. 10, p. 1). An analysis of the metaphors built on the Nahua term for "parent" will show that within the conceptual framework of this culture teaching and engendering were, in fact, very close to each other.

\section{THE DUALITY OF A NAHUA "PARENT"}

The discussion of the cultural construction of "father" cannot be complete without taking into account the category of "parent." In Spanish, this concept is rendered with the plural form of the term "father," padres. Nahuatl employed for this purpose a doublet -nan -tah, "mother-father," which described the concept by 
referring to its two constituent parts. The doublet served as a metaphor to describe, among others, rulers and gods, for whom, as has been mentioned above, the Spanish terminological system reserved the term "father." Needless to say, the logic that governed the extension of -nan -tah into non-kinship contexts did not follow Spanish mindset but was, instead, consistent with Nahua culture. An example of the usage of the term "parent" in a way entirely foreign to Europeans is found in the Florentine Codex, in the context of an exchange of traditional speeches by the elders of two families. Those who have just listened to a speech say to the speakers: "[y]our breath has ended, in each place you provided them [a young couple] with knowledge, in each place you provided them with life, you had nothing more to confer. Likewise we, who are the elders, have gone to take it, to grasp it once again: in this way you are our parents, in this way we once again become your children" (ca oontlatlan in amjhijotzin, ca onovian anqujmonmahaxitilique, onovian anqujmonmonemjtilique: aoc tle oanconmocavitzinoque. Auh no ivi in tehoantin in tivevetque, in tilamatque otoconcujque, otoconanque in oc ceppa ic antonantzitzinoan, in antotatzitzinoan: ic oc ceppa, ic tamopilhoan titochioa; Sahagún 2012:bk. 6, p. 145).

This kind of speech was called huehuehtlahtolli, that is, "the words of the elders," and one of its main functions was to convey oral tradition to younger generations. The value of huehuehtlahtolli, however, resided not only in the knowledge they were transmitting but also in the general qualities of speech, and even more basically, of breath. Olivier (2004:33-34) notes that, in Nahua culture, speech, and breath were equivalent to human sacrifice or autosacrifice, in that they both were requested from people by gods as a form of cult. Among the Maya, the act of speaking was believed to provoke the transmission of essence with creative potential, necessary for activities such as governing or communicating with the supernatural (Houston et al. 2006:153). The same was true for the Nahuas, who associated creation with both speaking and the flowing of blood, acts which, at the same time, served to establish contact with the supernatural (Olivier 2004:34-35). The reason why breath and blood played such an important role in relations between humans and gods was that they both carried large amounts of precious vital essence and could have been used for transmitting it to other persons or beings (López Austin 1984: 179-181; Martínez González 2011:45). Thus, the elders who had listened to a huehuehtlahtolli, enjoyed more than the wisdom of ancient words. By referring to the speakers as their "parents," they metaphorically acknowledged the transmission of vital essence that had just occurred and of which they had become beneficiaries. Such a metaphorical usage of the term "mother-father" suggests that in precontact Nahua culture the act of receiving education was perceived in terms of coming into being. Nahua parents (and "parents") provided life to their children (and "children") not only on a biological level, but also in terms of socialization.

Another passage from Book 6 of the Florentine Codex mentions a "mother-father" who uses blood, instead of breath, to transmit vital essences. A war leader is called the "parent" of the sun, because he virtually nourishes it with blood by providing captives who would die on sacrificial stones: "[Tloqueh Nahuaqueh] makes him govern the seat of valiant warriors; he makes him responsible for human sacrifice. He becomes the parent of the sun, he serves drinks; he serves food in the otherworld" (qujpacholtia in quappetlatl, in ocelopetlatl, imac qujmanjlia, in quauhxicalli, in quappiaztli: iehoatl tonatiuh inan ita muchioa: iehoatl teatlitia, tetlamaca in topã in mjctlan; Sahagún 2012:bk. 6, p. 88). This passage clearly shows a difference between the Spanish and Nahua metaphorical systems: an interpretation of the warrior as the "ruler" or "origin" of the sun (according to metaphorical connotations of padre) would make little sense, while seeing him from the perspective of a "giver" is perfectly compatible with Nahua culture.

When the ceremonies of Huey Tozoztli were coming to an end, the tree called totah was taken in a canoe to a place called Pantitlan, where there was a whirlpool believed to be an entrance to the realm of Tlaloc (Contel 2008:175). The tree was then planted in the mud next to the whirlpool, where it was to remain until it rotted and fell apart. This ritual act was followed by a sacrifice of a seven- or eight-year-old girl who represented lakes, streams, and springs: her throat was sliced, blood let into the water, and the body "swallowed" by the lake. It should be noted that children were typical sacrificial victims offered to Tlaloc. According to Contel (2008:174-178), the children were equivalent to chalchihuitl, or precious greenstones, and Durán (2005:142-145) writes that, during Huey Tozozotli, the sacrificed girl went to the water accompanied by precious stones, but also gold, silver, and pieces of jewelry. Interestingly, when telling stories about Pantitlan, the Spanish friar once lets escape the phrase nuestra madre la laguna, "our mother the lake," and it is highly unlikely that he would come up with such a denomination on his own. If the term "our mother," which in Nahuatl would have been tonantzin, betrays the genuine name of the sacrificial site, given to the friar by his native informants, we are dealing here with a ritual that, on the level of cultural communication, can be perceived as equivalent to the doublet -nan -tah in oral discourse. Heyden (1993:215-216) suggests that planting a tree next to the whirlpool symbolized a union of the two "deities" and indeed, the phallic shape of the tree, the watery place where it was left, and the flow of vital essence contained in the blood of the sacrificed girl, all are reminiscent of an act of conception. In an anticipation of fertility- the principal gift asked from Tlaloc - in Pantitlan the fiery, masculine, and hot "father" joined with the watery, feminine, and cold "mother." Here, we are possibly dealing with another example of gender complementarity observed by scholars in many Nahua rituals and beliefs.

The lake described by Durán (2005:144) was a dangerous and scary place, where many drownings occurred due to mysterious underwater movements. Similarly, deities referred to as people's "mothers-fathers" were believed not only to guarantee the existence of all mankind but at the same time to be responsible for death and destruction. For example, Tonatiuh (the sun) and Tlalteuctli (the earth) provided people with heat and cold essences of growth, respectively, but they also received warriors killed in battle: "let them peacefully, calmly, lie down in the womb, breast, arms of our parent, Tonatiuh, Tlalteuctli" (ma ivian, iocoxca yxillan, itozcatlan, imacochco ommoteca in tonan, in tota, in tonatiuh in tlaltecutli; Sahagún 2012:bk. 6, p. 88). The combination of heat and cold was characteristic of the supreme creator deity, Tloqueh Nahuaqueh (Olko 2014:330), who, in the Florentine Codex, is called the "parent" of a newborn baby (Sahagún 2012:bk. 6 , p. 169). His other name, Ometeuctli Omecihuatl, reflected his dual, masculine-feminine nature and was likewise employed together with the doublet -nan -tah (Sahagún 2012:bk. 6, p. 183).

On earth, the creator deity was represented by rulers who bore the title of tlahtoani, or "speaker," and through whom the god pronounced his words (Olivier 2002:123; Sahagún 2012:bk. 6, p. 41). It is very likely that in the Nahua world, the tlahtoani's breath was 
believed to be hot and cold at the same time. The attributes of royal authority were repositories of both kinds of essence, for example turquoise was closely associated with fire and heat, while jade attracted the cold forces of growth (Olko 2014:314). It is precisely these precious stones royal words (tlahtohcatlahtolli) are compared to in the Florentine Codex (Olko 2010:172; Sahagún 2012:bk. 6, p. 99). Tlahtohqueh (the plural of tlahtoani) operated on both plains of the dual universe, constituting sources of light and heat on the one hand, and guaranteeing fertility and seasonal rebirth of plants on the other hand (Olko 1999:118, 2014:26). The latter aspect of their dual nature was present, for example, during the celebrations of the feast Huey Tozoztli, in which tlahtohqueh played an essential role (Durán 2005:137; Olko 1999:118). Moreover, similarly to Tloqueh Nahuaqueh and other creative-destructive deities, the rulers were believed to act in both ways, bringing both consolation and destruction to their vassals:

The commoner will honor him, [the tlahtoani] will be his mother-father, he will wipe away the tears of the common people, he will bathe them in water, he will clean them. He will separate (the commoner] from what causes his downfall, the commoner will disintegrate in his hands, he will be shattered in his hands, because Tloqueh Nahuaqueh indeed gave favor to [the tlahtoani]. (ieh hacovic, tlalchivic qujttaz in maceoalli, inan yta iez, ie qujxayopapachotiez in cujtlapilli, yn atlapalli: ie cahaltiz, ie qujpapacaz: auh ie qujcotonjliz in jpolivia, in jacoqujçaia, ie imac xamanjz, imac teinjz in maceoalli: Ca nel noço oqujcnoma in tloque naoaque; Sahagún 2012:bk. 6, p. 84). [From other contexts in Book 6 (Sahagún 2012:bk. 6, pp. 9, 26, 29, 41), it appears that polihui acoquiza, "to perish, to grow or elevate oneself" is a metaphor for ruining oneself.]

Montes de Oca (2013:124-138) notes that the most common metaphors for a ruler in Book 6 of the Florentine Codex are based on the concepts of "mother-father," "shadow," and "tree" ( pochotl ahuehuetl, "silk cotton tree, cypress"). According to her, all three referred to protection and guidance as important functions and skills of a tlahtoani. The doublet -nan -tah could indeed have described a specific kind of protection exercised by the ruler through delivering vital essence to the altepetl. The same understanding of protection may have been implied by the doublet pochotl ahuehuetl, interpreted by López Austin (2003:151) as referring to the transmission of hot and cold divine "messages" to tlahtoani's people. While protective functions of parents and large trees are acknowledged by Western culture, it is important to look beyond superficial parallels. Similarly to Nahua "fathers," Nahua "mothersfathers" were involved in the process of transmission, or, from another point of view, of communication, employing breath and blood as media. A union of masculinity and femininity produced a complex "message" of hot and cold nature: at the same time celestial and terrestrial, its latter aspect was associated with both life and death. Such precious "gifts" were offered not only by gods but by all beings metaphorically named "mothers-fathers": rulers, warriors, or elders.

\section{NEW USAGES OF "PARENTAL" METAPHORS}

In Colonial written sources, Nahua "fathers" as "heat-givers" (deities, trees, priests, or tlahtohqueh) contrast with Spanish "fathers" as "power-holders" and "origins" (God, saints, and priests). In between, however, lies a grey area of metaphorical extensions of -tah that cannot be easily ascribed to either cultural background. The bilingualism and bi-culturalism of Nahua-Christian authors gave rise to hybrids or new usages of terms, in which both traditions merged. An interesting example of this phenomenon is to be found in Fray Andrés de Olmos' Huehuetlatolli, where the ecclesiastics are referred to as in monanhuan in motahhuan in padremeh, "your mothers, your fathers, the priests" (Bautista 2008:f. 56r). Since the text stresses the role of the ecclesiastics as teachers many times (e.g., in amoteizcalihcahuan in amotemachtihcahuan in padremeh, "your tutors, your teachers, the priests" [Bautista 2008:f. 55v]), we can assume that the metaphor was used intentionally. It is all the more unique because the kin term usually employed for priests in both Nahua and Spanish cultures was "father"- the "father" of a deity in the former and "our father" in the latter. The author of the huehuehtlahtolli resorted to neither of them, instead equaling the ecclesiastics with the elders who passed the oral tradition on to younger generations.

Other examples come from mundane documents, such as testaments, petitions, or complaints. These sources apply the Nahuatl term "father" to patron-saints, understood as "fathers" of entire communities, churches, cofradías (religious sodalities) or households (Madajczak 2011). While Christian saints were normally called "fathers" by the Spaniards, sixteenth-century Nahua patron-saints were so well adapted to traditional rituals and beliefs that their "fatherhood" may have as well implied the Nahua notion of transmission (although direct evidence for this is yet to show up in sources). In a more down-to-earth context, and in spite of the prevalent use of the doublet -nanhuan-tahhuan for family elders in the Florentine Codex, the elders of communities (altepetl) were sometimes called tetahhuan ("the fathers of people") (Lockhart 1992: 154), totahhuan ("our fathers") (e.g., Reyes García et al. 1996:78, 80), or notahhuan ("my fathers") (Pizzigoni 2007:241). We can speculate that the extraction of "father" from the femininemasculine doublet may have followed the masculinization of authority in colonial society.

Available sources do not provide explicit information on the exact path of changes in Nahua worldview or worldviews and the scope of this paper does not allow for a detailed comparison of concepts of paternality to other concepts (mostly those outside of the kinship realm) that underwent a similar fusion with Spanish cultural expressions. One such concept that has already attracted the attention of scholars is "tree." Russo (1998:32) notes that a depiction of a nopal cactus growing out of the body of the sacrificed Copil in the Códice Azcatitlan is similar to a common convention for representing the genealogy of Jesus Christ, the "tree of Jesse." According to her, this similarity may indicate that the author of the Nahua image was inspired by Christian iconography. In the same vein, Haskett (2005:287-291) notes a possible merging in the Nahua imaginary of a cross and a tree, based on the Spanish reference to the "tree of the cross" on the one hand, and on Nahua concepts such as totah of Huey Tozoztli on the other. As in the case of "father," in each of the two cultures the "sacred tree" (whether totah or cross) was considered to be a source of life, though rooted in a completely different system of beliefs.

\section{CONCLUSION}

Linguistic evidence from written sources clearly tells us that these texts arose from the encounter of two languages and, at the same time, two cultures. The easiest way to appreciate this combination is 
to look at multiple Spanish loanwords incorporated in the Nahuatl discourse. What cannot be visible at first glance, however, is the encounter of the two different ways of conceptualizing the world. New concepts were not simply borrowed by the Nahuas: they were re-interpreted and assimilated in the network of their own beliefs, while the Spanish authors of texts did the same with Nahua categories. Therefore, a study of native terminologies requires an examination of the two sides of the coin. Seeking to understand precontact cultures on the basis of written sources is inseparable from analyzing the Colonial discourse through which these cultures have been filtered.

The analysis of the Nahua concept of "father" demonstrates that even seemingly universal categories were substantially different within European and Native American worldviews. For both cultures to be a "father" meant to be a giver of life. In early modern Spain, however, this role was inscribed in the hierarchical model of the universe and implied being the origin of things and hence (within this logic)—holding power. For the Nahuas a vertical hierarchy was not the most important organizational principle: their logic was based on the concept of exchange. Whereas in the Spanish cultural construction of "father" the focus was on the father as one who initiates life, the Nahuas emphasized that he gives life, understood in terms of animating essence. For European readers a troublesome fact has been that these two systems appeared to have had some points in common. For example, in both Spanish and Nahuatl a dynastic ruler is metaphorized as "father" (though in the latter it is "mother-father"): is this not proof that both cultures perceived "paternity" in the same way? If one looks at other usages of "parental" metaphors in sources, it is not. A warrior is by no means the "origin" or "ruler" of the sun, nor does a priest perform such a role in regard to deities. What they all have in common is the participation in the circle of exchange, where "fathers" are the "givers" (see Madajczak 2015 for the reciprocal role of "children").
A study on Nahua metaphors such as "father" helps to avoid misreadings of precontact Nahua texts. At the same time, the concept of "father" as "life-giver" has implications not only for our understanding of Nahua deities, tlahtohqueh, or priests but also for our insight into Nahua ideology of kinship and the role of father within the family and gender relations in Nahua society. Evidence suggests that engendering a child was conceived of as a process rather than an act and that it was followed by second "engendering" through socialization. In their deconstruction of the myth of male dominance in Aztec society, McCafferty and McCafferty (1988:46) reject the notion of a "gender hierarchy" "as an overly formal, normative structure, which masks many interesting relationships." Instead of looking for a hierarchical position of the father within a family, I have tried to explore some elements of the Nahua idea of fatherhood. Nahua fathers gave life to their children, passed knowledge to them, and acted as sources of tonalli that flowed during these two activities. Although the concept of "mother" has not been analyzed here, the use of the doublet -nan -tah suggests that mothers, like all women, could have been associated with the cold and humid sphere of the cosmos, fulfilling a role partly parallel and partly complementary to that of "hot" fathers.

Finally, it is important to acknowledge that, alongside Nahua and Spanish metaphors, Colonial sources in Nahuatl used new terminology (and new iconography), which, although rooted in both traditions, expressed ideas of a world never seen before either by Nahuas or Spaniards. An insight into a precontact idea of fatherhood and "fatherhood" contributes to identification of some of these uses and, in the future, perhaps to a better understanding of the historical process that produced them. In the fields that must draw from limited and often obscured data, such as Mesoamerican Studies, metaphors may offer a window to these aspects of culture that were not openly revealed in texts.

\section{RESUMEN}

Este artículo presenta un análisis de varios términos en nahuatl para „padre.” Lo hace a partir de las fuentes escritas en náhuatl y en español durante el periodo colonial, sobre todo en su primera mitad (desde el siglo XVI hasta los principios del siglo XVII). El objetivo principal de la investigación es reconstruir el concepto prehispánico de "padre," ocultado en las fuentes bajo el fuerte sustrato cristiano. El análisis se lleva a cabo en varios niveles. Primero, se hace una prueba de separar los usos cristianos de los términos para "padre" de sus usos tradicionales dentro del marco prehispánico. Lo que sigue es el análisis contextual de las occurrencias de estos últimos con los sentidos metafóricos, para llegar a los criterios lógicos de la extensión de estos términos de parentesco a otros campos. El trabajo finaliza con unas observaciones sobre usos que no caben en ningún de los dos sístemas de clasificación.

$\mathrm{El}$ anális de las metáforas basadas en los términos -tah ("padre") y -nan -tah ("madre-padre," parent) lleva a la conclusión de que en la época prehispánica se denominaba "padres" a las personas que transmitían un tipo de esencia calurosa (tonalli). En la cosmovisión de los antiguos nahuas el "calor" o el "fuego" fue una de las fuerzas de las que dependía la existencia del mundo. El Sol lo comía para poder seguir con su movimiento en el cielo y los humanos lo recibían para poder vivir en la tierra. La sangre humana (o los corazones) y el aliento (o las palabras) contenían grandes cantidades de esta esencia. Por lo tanto, en las fuentes se llama "padre" a un soldado que proporciona al Sol las víctimas del sacrificio o a unos ancianos que dan un discurso sobre la tradición. En contraste con el pensamiento europeo, que situa al "padre" en el marco jerárquico ("padre" es gobernante, autoridad u origen), esta lógica se apoya en la ideología de intercambio en la que los "padres" son dadores y los "hijos" son recibidores. Esta conclusión tiene sus implicaciones para la construcción indígena del concepto de padre biológico. Parece que al igual que la sangre y el aliento, también el semen fue considerado un medio para transferir tonalli. De esta manera el padre fue literalmente "dador de vida" -tal como en la tradición europea, pero solo en la superficie. El material recopilado en este trabajo permite ver la complejidad y originalidad de la ideología nahua de parentesco, así como las diferencias notables entre esta y la ideología de los autores españoles del periodo colonial. Al mismo tiempo, los resultados obtenidos contribuyen al mejor entendimiento de los textos en nahuatl, en los que las metáforas son demasiado frecuentemente leídas según la lógica europea y no indígena. 


\section{ACKNOWLEDGMENTS}

This work was supported by the European Research Council under Starting Grant FP7-IDEAS-ERC-312795. Unless otherwise noted, all translations are my own. I owe my deep gratitude to Justyna Olko, Agnieszka Brylak, and Katarzyna Szoblik, who reviewed the manuscript, provided invaluable comments, offered inspiration, and shared their books and electronic resources. I should be held responsible for any errors found in the paper. John Sullivan generously spared his time to discuss with me etymological issues regarding

\section{REFERENCES}

Anderson, Arthur J. O., Frances Berdan, and James Lockhart

1976 Beyond the Codices: The Nahua View of Colonial Mexico. University of California Press, Berkeley.

Anonymous

1548 Doctrina cristiana en lengua española y mexicana por los religiosos de la orden de Santo Domingo. Manuscript on file, Biblioteca Nacional de España, Madrid.

Bassett, Molly H.

2015 The Fate of Earthly Things: Aztec Gods and God-Bodies. University of Texas Press, Austin.

Bautista, Juan

2008 [1601] Huehuetlatolli. Paleography by Isis Zempoalteca Chávez. Electronic document, http://www.sup-infor.com, accessed January 13, 2016.

Burkhart, Louise M.

1989 The Slippery Earth: Nahua-Christian Moral Dialogue in Sixteenth-Century Mexico. University of Arizona Press, Tucson.

1997 Mexica Women on the Home Front: Housework and Religion in Aztec Mexico. In Indian Women of Early Mexico, edited by Susan Schroeder, Stephanie Wood, and Robert Haskett, pp. 25-54. University of Oklahoma Press, Norman.

2001 Before Guadalupe: The Virgin Mary in Early Colonial Nahuatl Literature. Institute for Mesoamerican Studies, Albany.

Calnek, Edward E.

1974 The Sahagún Texts as a Source of Sociological Information. In Sixteenth-Century Mexico, edited by Munro S. Edmonson, pp. 189-204. University of New Mexico Press, Albuquerque.

Carrasco, Pedro

1966 Sobre algunos terminos de parentesco en el náhuatl clásico. Estudios de Cultura Náhuatl 6:149-166.

Chimalpahin, Domingo Francisco de San Antón Muñón Quauhtlehuanitzin

2006 Annals of His Time. Edited and translated by James Lockhart, Susan Schroeder, and Doris Namala. Stanford University Press, Stanford.

Chimalpahin, Domingo Francisco de San Antón Muñón Quauhtlehuanitzin, and Hernando de Alvarado Tezozomoc

1997 Mexican History or Chronicle. In The Codex Chimalpahin, Vol. 2, edited and translated by Susan Schroeder and Arthur J.O. Anderson, pp. 27-178. University of Oklahoma Press, Norman.

Cline, Sarah L., and Miguel León-Portilla (editors)

1984 The Testaments of Culhuacan. University of California Los Angeles Latin American Center Publications, Los Angeles.

Contel, José

2008 Tlálloc, el cerro, la olla, y el chalchihuitl. Una interpretación de la lámina 25 del Códice Borbónico. Itinerarios 8:153-184.

Contel, José, and Katarzyna Mikulska

2011 "Mas nosotros que somos dioses nunca morimos". Ensayo sobre tlamacazqui: ¿Dios, sacerdote, o que otro demonio? In De dioses y hombres. Creencias y rituales mesoamericanos y sus supervivencias, edited by Katarzyna Mikulska and José Contel, pp. 23-65. Encuentros 2010, Vol. 5. Instituto de Estudios Ibéricos e Iberoamericanos, University of Warsaw, Warsaw, and Institut de Recherches Intersites Etudes Culturelles, University of Toulouse, Toulouse.

Covarrubias Orozco, Sebastián de

1611 Tesoro de la lengua castellana o española. Luis Sánchez, Madrid. Electronic document, http: / fondosdigitales.us.es/fondos/libros/765/ 1184/tesoro-de-la-lengua-castellana-o-espanola/, accessed December 20, 2015. izcalia and to review my translations of the passages in Spanish. I am grateful to Juan José Batalla Rosado for providing me with a high-quality image of the totah tree and to Jean Silk and Robert Borges for reviewing the English of the paper. Last but not least, I thank Katarzyna Mikulska, Jerome Offner, José Luis de Rojas, and Ryszard Tomicki for commenting upon the sections of my $\mathrm{PhD}$ dissertation, from which this paper partially draws.

Díaz Rubio, Elena

1986 Acerca de la terminología de parentesco en el náhuatl clásico: Tlacamecayotl. Revista Española de Antropología Americana 16:63-80. Douglas, Mary

1999 Implicit Meanings: Selected Essays in Anthropology. 2nd ed. Routledge, London.

Durán, Fray Diego

1991 [1587] Historia de las Indias de Nueva España e Islas de Tierra Firme, Vol. 2. Banco Santander, Madrid.

2005 Historia de las Indias de Nueva España e islas de tierra firme, Vol. 2. Facsimile ed. Biblioteca Virtual Miguel de Cervantes, Alicante. Electronic document, http://www.cervantesvirtual.com, accessed January 13, 2016.

Gardner, Brant

1982 A Structural and Semantic Analysis of Classical Nahuatl Kinship Terminology. Estudios de Cultura Náhuatl 15:89-124.

Graulich, Michel

1982 Tlacaxipehualiztli ou la fête aztèque de la moisson et de la guerre. Revista Española de Antropología Americana 12:215-154.

Haskett, Robert

2005 Visions of Paradise: Primordial Titles and Mesoamerican History in Cuernavaca. University of Oklahoma Press, Norman.

Heyden, Doris

1993 El árbol en el mito y el símbolo. Estudios de Cultura Náhuatl 23 . 201-219.

Houston, Stephen, David Stuart, and Karl Taube

2006 The Memory of Bones: Body, Being, and Experience among the Classic Maya. University of Texas Press, Austin.

Johansson, Patrick

2002 Review of Fiestas de los pueblos indígenas. Ritos aztecas: las fiestas de las veintenas, by Michel Graulich. Estudios de Cultura Náhuatl 33:389-391.

Joyce, Rosemary A.

2000 Gender and Power in Prehispanic Mesoamerica. University of Texas Press, Austin.

Karttunen, Frances

1992 An Analytical Dictionary of Nahuatl. University of Oklahoma Press, Norman.

Karttunen, Frances, and James Lockhart

1976 Nahuatl in the Middle Years: Language Contact Phenomena in Texts of the Colonial Period. University of California Press, Berkeley.

Karttunen, Frances, and James Lockhart (editors)

1987 The Art of Nahuatl Speech: The Bancroft Dialogues. University of California Los Angeles Latin American Center Publications, Los Angeles.

Kellogg, Susan M.

1986 Kinship and Social Organization in Early Colonial Tenochtitlan. In Ethnohistory, edited by Ronald M. Spores, pp. 103-121. Supplement to Handbook of Middle American Indians, Vol. 4. University of Texas Press, Austin.

1997 From Parallel and Equivalent to Separate but Unequal: Tenochca Mexica Women, 1500-1700. In Indian Women of Early Mexico, edited by Susan Schroeder, Stephanie Wood, and Robert Haskett, pp. 123-144. University of Oklahoma Press, Norman.

2005a Weaving the Past: A History of Latin America's Indigenous Women from the Prehispanic Period to the Present. Oxford University Press, New York.

2005b Law and Transformation of Aztec Culture, 1500-1700. University of Oklahoma Press, Norman.

Klein, Cecelia F.

2001 None of the Above: Gender Ambiguity in Nahua Ideology. In 
Gender in Pre-Hispanic America, edited by Cecelia F. Klein, pp. 183-253. Dumbarton Oaks Research Library and Collection, Washington, DC.

Köhler, Ulrich

2001 "Debt Payment" to the Gods Among the Aztec: The Misrendering of the Spanish Expression and its Effects. Estudios de Cultura Náhuatl 32:125-133.

Lockhart, James

1992 The Nahuas after the Conquest: A Social and Cultural History of the Indians of Central Mexico, Sixteenth through Eighteenth Centuries. Stanford University Press, Stanford.

2001 Nahuatl as Written: Lessons in Older Written Nahuatl with Copious Examples and Texts. Stanford University Press, Stanford, and University of California Los Angeles Latin American Center Publications, Los Angeles.

López Austin, Alfredo

1974 The Research Method of Fray Bernardino de Sahagún: The Questionnaires. In Sixteenth-Century Mexico: The Work of Sahagún, edited by Munro S. Edmonson, pp. 111-149. University of New Mexico Press, Albuquerque.

1984 Cuerpo humano e ideología: Las concepciones de los antiguos nahuas, Vol. 1. 2nd ed. Universidad Nacional Autónoma de México, Mexico City.

2000 Tamoanchan y Tlalocan. Fondo de Cultura Económica, Mexico City.

2003 Difrasismos, cosmovisión e iconografía. Revista Española de Antropología Americana Vol. Extraordinario 1:143-160.

2006 Los mitos del tlacuache. 4th ed. Universidad Nacional Autónoma de México, Mexico City.

Maffie, James

2015 Aztec Philosophy. Understanding a World in Motion. University Press of Colorado, Boulder.

McCaa, Robert

2000 The Geometry of Gender among the Ancient Aztecs: "Earthly Names," Pre-teen Marriage, and the Female Places in the Household. Electronic document, http://www.hist.umn.edu/ rmccaa/AZTCNAM2/ nahuanms.doc, accessed January 13, 2016.

Madajczak, Julia

2011 Holy Family: Nahuatl Kinship Terms in the Context of Christianity. Estudios de Cultura Náhuatl 41:109-138.

2015 Nahuatl Kinship Terminology as Reflected in Colonial Written Sources from Central Mexico: a System of Classification. Ph.D. dissertation, Faculty of Artes Liberales, University of Warsaw, Warsaw.

Martínez González, Roberto

2011 El Nahualismo. Universidad Nacional Autónoma de México, Mexico City.

McCafferty, Sharisse D., and Geoffrey G. McCafferty

1988 Powerful Women and the Myth of Male Dominance in Aztec Society. Archaeological Review from Cambridge 7:45-59.

Molina, Fray Alonso de

1977 [1571] Vocabulario en lengua castellana y mexicana y mexicana y castellana. 2 vols. 2nd ed. Editorial Porrúa, Mexico City.

1984 [1569] Confessionario mayor en la lengua mexicana y castellana. Edited by Roberto Moreno. Facsimile ed. Universidad Nacional Autónoma de México, Mexico City.

Monaghan, John

1995 The Covenants with Earth and Rai: Exchange, Sacrifice, and Revelation in Mixtec Sociality. University of Oklahoma Press, Norman.

Montes de Oca, Mercedes

2013 Los difrasismos en el náhuatl de los siglos XVI y XVII. Universidad Nacional Autónoma de México, Mexico City.

Offner, Jerome A.

1983 Law and Politics in Aztec Texcoco. Cambridge University Press, Cambridge.

Olivier, Guilhelm

2002 The Hidden King and the Broken Flutes: The Mythical and Roya Dimension of Tezcatlipoca's Feast in Toxcatl. In Representing Ritual: Performance, Text and Image in the Work of Sahagún, edited by Eloise Quiñones Keber, pp. 107-142. University of Colorado Press, Niwat.

2004 Tezcatlipoca: Burlas y Metamorfosis de un Dios Azteca. Translated by Tatiana Sule. Fondo de Cultura Económica, Mexico City.

2010 El simbolismo sacrificial de los Mimixcoa: cacería, guerra, sacrificio e identidad entre los Mexicas. In El Sacrificio Humano en la
Tradición Religiosa Mesoamericana, edited by Leonardo López Lújan and Guilhelm Olivier, pp. 453-482. Universidad Nacional Autónoma de México, Mexico City.

Olko, Justyna

1999 Hierogamy in the Aztec Ritual. Estudios Latinoamericanos 19: 101-132.

2010 Meksyk przed konkwista. Państwowy Instytut Wydawniczy, Warsaw.

2014 Insignia of Rank in the Nahua World: From the Fifteenth to the Seventeenth Century. University Press of Colorado, Boulder.

Pizzigoni, Caterina

2007 Testaments of Toluca. Stanford University Press, Stanford and University of California Los Angeles Latin American Center Publications, Los Angeles.

2012 The Life Within: Local Indigenous Society in Mexico's Toluca Valley, 1650-1800. Stanford University Press, Stanford.

Rammow, Helga

1964 Die Verwandtschaftsbezeichnungen im klassischen Aztekischen. Herausgegeben vom Hamburgischen Museum für Völkerkunde und Vorgeschichte, Hamburg.

Real Academia Española

1726-1739 Diccionario de Autoridades. Electronic document, http:// web.frl.es/DA.html, accessed November 22, 2013.

Reyes García, Luis, Eustaquio Celestino Solís, Armando Valencia Ríos,

Constantino Medina Lima, and Gregorio Guerrero Díaz (editors)

1996 Documentos nauas de la Ciudad de México del siglo XVI. Centro de Investigaciones y Estudios Superior en Antropología Social and Archivo General de la Nación, Mexico City.

Ricoeur, Paul

2003 The Rule of Metaphor. 2nd ed. Translated by Robert Czerny. Routledge, Taylor and Francis, London.

Ruíz de Alarcón, Hernando

1987 [1629] Treatise on the Heathen Superstitions That Today Live Among the Indians Native to This New Spain, 1629. Edited and translated by J. Richard Andrews and Ross Hassig. University of Oklahoma Press, Norman

Russo, Alessandra

1998 El renacimiento vegetal. Árboles de Jesé entre el Viejo Mundo y el Nuevo. Anales del Instituto de Investigaciones Estéticas 20(73):5-39

Sahagún, Bernardino de

1997 Primeros memoriales. Edited and translated by Thelma D. Sullivan and Henry B. Nicholson. University of Oklahoma Press, Norman.

2012 Florentine Codex: General History of the Things of New Spain. 12 vols. Edited and translated Arthur J.O. Anderson and Charles E. Dibble. Rev. 2nd ed. The School of American Research, Santa Fe, and the University of Utah, Salt Lake City.

Schwaller, John F.

2006 The Ilhuica of the Nahua: Is Heaven Just a Place? The Americas 62:391-412.

Sigal, Pete

2011 The Flower and the Scorpion: Sexuality and Ritual in Early Nahua Culture. Duke University Press, Durham.

Szoblik, Katarzyna

2007 El papel de las Ahuianime en la sociedad Azteca. Unpublished Master's thesis, Faculty of Modern Languages, University of Warsaw, Warsaw.

Tavárez, David

2000 Naming the Trinity: From Ideologies of Translation to Dialectics of Reception in Colonial Nahua Texts, 1547-1771. Colonial Latin American Review 9:21-47.

Todorov, Tzvetan

1999 The Conquest of America: The Question of the Other. Translated by Richard Howard. University of Oklahoma Press, Norman.

Umberger, Emily

1999 The Reading of Hieroglyphs on Aztec Monuments. Thule 6/7: 77-102.

Wood, Stephanie (editor)

2016 Nahuatl Dictionary. Wired Humanities Project. Electronic document, http://whp.uoregon.edu/dictionaries/nahuatl/index.lasso, accessed December 16, 2013. 